\title{
Contribution of monitoring data to decision making for evacuation from the 2014 and 2015 eruptions of Kuchinoerabujima Volcano
}

\author{
Masato Iguchi*, Haruhisa Nakamichi*, Takeshi Tameguri*, Keigo Yamamoto*, Toshiya Mori**, \\ Takao Ohminato***, Eiji Saito**** \\ *Sakurajima Volcano Research Center, Disaster Prevention Research Institute, Kyoto University \\ **Geochemical Research Center, Graduate School of Science, University of Tokyo \\ ***Earthquake Research Institute, University of Tokyo \\ ****Geological Survey of Japan, National Institute of Advanced Industrial Science and Technology
}

(Received: Nov. 06, 2016 Accepted: Apr. 05, 2017)

\begin{abstract}
On August 3, 2014 and May 29, 2015, eruptions occurred at the Shindake summit crater of Kuchinoerabujima Volcano, which is located in the Ryukyu Islands in southwestern Japan. The Japan Meteorological Agency upgraded the Volcanic Alert Level (VAL) to 3 (restricted zone within $2 \mathrm{~km}$ from the summit) after the 2014 eruption and to 5 (evacuation) after the 2015 eruption. The possibility of implementing early warnings for eruptions and forecasting the area most likely to suffer damage from volcanic eruptions was examined based on monitoring data and the disaster areas of historic eruptions. A long-term process spanning 15 years and a relatively short-term process that could have been implemented immediately before the onset of the 2014 eruption were identified. The seismicity, which mostly represented extremely shallow (less than $0.5 \mathrm{~km}$ ) volcano-tectonic earthquakes beneath the summit crater, increased from July to December 1999. After the first increase in seismicity, several repeated bursts of seismicity occurred. Repeated ground inflation events around the crater detected by continuous GNSS were associated with the increase in seismicity. Increases in the activity were also accompanied by increases in geothermal and fumarolic activity. An alert zone of 1 or $2 \mathrm{~km}$ (VAL 2 or 3) from Shindake crater was established immediately after three bursts of volcanic earthquakes occurred during the precursory period of the 2014 eruption. However, there were no definite indications to trigger an upgrade to the VAL before the 2014 eruption because the relatively high volcanic activity had been stable and the precursory tilt change began only a short time before the eruption. The phenomena prior to the 2015 eruption were more intense than those prior to the 2014 eruption, as demonstrated by the seismicity, which included a felt earthquake six days before the eruption; the larger ground deformation; the higher rate of discharge of $\mathrm{SO}_{2}$ gas; and the higher temperature. Among these precursors, the felt earthquake could be considered an appropriate indication to trigger an upgrade of the VAL from 3 to 5 for evacuation because felt earthquakes suddenly increase the seismic energy, whereas other parameters showed gradual progress. In historical cases, a few felt earthquakes were reported prior to the eruptions in 1931 and 1966. The felt earthquake before the 2015 eruption was induced by the accumulation of other eruption-related parameters, such as an increase in the $\mathrm{SO}_{2}$ discharge rate, the inflation of the volcano, and the appearance of volcanic glow at the summit. Decreases in the seismicity, $\mathrm{SO}_{2}$ gas discharge rate, and geothermal activity led to an initial reduction of the alert zone radius to less than $2.5 \mathrm{~km}$ in October 2015, and a further reduction to less than $2 \mathrm{~km}$ (VAL 3) was later implemented based on the deflation around the summit area in June 2016.
\end{abstract}

Keywords: volcanic eruption, Kuchinoerabujima Volcano, volcanic alert level, volcanic earthquake, deformation 


\section{Introduction}

Kuchinoerabujima Volcano is an island volcano located $14 \mathrm{~km}$ west of the island of Yakushima. The volcano is composed of the old cones of Ban-yagamine, Hachikubo, and Kashimine Volcanoes and the central cones of Noike, Furudake, and Shindake Volcanoes (Geshi and Kobayashi, 2006). The historical record of the eruption of Kuchinoerabujima Volcano dates back to 1841, when a crater at the summit of Shindake erupted. As a result of the 1841 eruption, a village $2 \mathrm{~km} \mathrm{WNW}$ of the crater was buried in pyroclastic material and rebuilt $3 \mathrm{~km}$ away from the crater. After the 1841 eruption, additional eruptions occurred at the crater and a north-south-striking fissure east of Shindake. Eruptions occurred frequently at Shindake crater during the period from 1931 to 1934. An eruption on April 2, 1931 destroyed the northwestern rim of the crater, and the pyroclastic material it produced reached the village of Mukaehama, $2 \mathrm{~km}$ away from the crater. An eruption on December 24, 1933 left eight people dead and 26 injured due to volcanic bombs that reached a distance of $2 \mathrm{~km}$. Similarly, ballistic bombs ejected by the vulcanian eruptions on November 22, 1966 flew to a distance of $3 \mathrm{~km}$. Eruptions occurred at a fissure east of Shindake crater in 1945 and 1980. The most recent eruption in 1980 was a phreatomagmatic eruption, which deceased shortly (Kyoto University et al., 1981) and it was not followed by any eruptive activity until 2014. The residents of nearby villages have sometimes evacuated to avoid danger from the eruptions of Kuchinoerabujima Volcano.

In December 1991, Kyoto University began the continuous seismic observation of the area around Kuchinoerabujima Volcano using a single seismometer, and the observation system has since been expanded by integrating seismometers, a tiltmeter, a global navigation satellite system (GNSS), and proton magnetometers and conducting repeated campaign observations. An increase in the seismicity of volcanic earthquakes was detected in July 1999 by this observation system (Iguchi et al., 2007; Triastuty et al., 2009). The Japan Meteorological Agency (JMA), which is responsible for monitoring volcanic activity and issuing warnings for volcanic eruptions, began to continuously monitor the seismicity of Kuchinoerabujima Volcano after the detected increase in seismicity in 1999, and the monitoring system has been upgraded since that time. Based on the obtained monitoring data, JMA has included the Volcanic Alert Level (VAL) in its issued volcanic warnings since December 2007 (Yamasato et al., 2013; Fujii, 2016). The VAL is a 5-point scale indicating the evaluated volcanic activity and actions to be taken by climbers or residents. A VAL of 1 is issued for the dormant stage of volcanic activity and no restriction is recommended. VALs of 2 and 3 are announced for climbers to refrain from restricted zones. A wider restricted zone is determined in the case of a VAL of 3. For residents around volcanoes, a VAL of 4 is issued to alert people to prepare to evacuate before the occurrence of eruptions and 5 to alert people to evacuate from restricted zones before or after the onset of the eruptions. Considering the severity of forecasted volcanic activity, the VAL of 5 before the eruptions represents the greatest severity. Local governments refer to the VAL when determining what countermeasures to take against volcanic disasters, such as making preparations for an evacuation.

After the seismicity increase in 1999, several earthquake swarms occurred, and inflations of the ground around Shindake crater were accompanied by increases in seismicity. In addition, a new fumarole appeared at the southern rim of the crater, and the fumarolic activity increased, with the white plume of the fumarole reaching an altitude of $500 \mathrm{~m}$ above the crater. An eruption occurred at Shindake crater at 12:24 on August 3, 2014, and the resulting volcanic ash cloud reached an elevation of $800 \mathrm{~m}$ above the crater. The western rim of the crater collapsed as a result of the eruption. Pyroclastic surges directed northwestward and southwestward reached a distance of nearly $2 \mathrm{~km}$ from the crater. JMA upgraded the VAL from 1 (normal) to 3 (restricted zone $2 \mathrm{~km}$ from the crater). The 2014 eruption was followed by a larger eruption at 09:59 on May 29, 2015. The volcanic plume reached an elevation of $10 \mathrm{~km}$ above the crater, and the pyroclastic flow reached a distance of more than $2 \mathrm{~km}$ from the crater. JMA upgraded the VAL from 3 to 5 (evacuation) immediately after the onset of the eruption, and 137 residents, including visitors, were evacuated from the island of Kuchinoerabujima to neighboring Yakushima by ferry. In this study, the possibility of implementing early eruption warnings and forecasting the area likely to suffer from volcanic disasters was examined based on observational data and the areas affected by historic eruptions. 


\section{Observation}

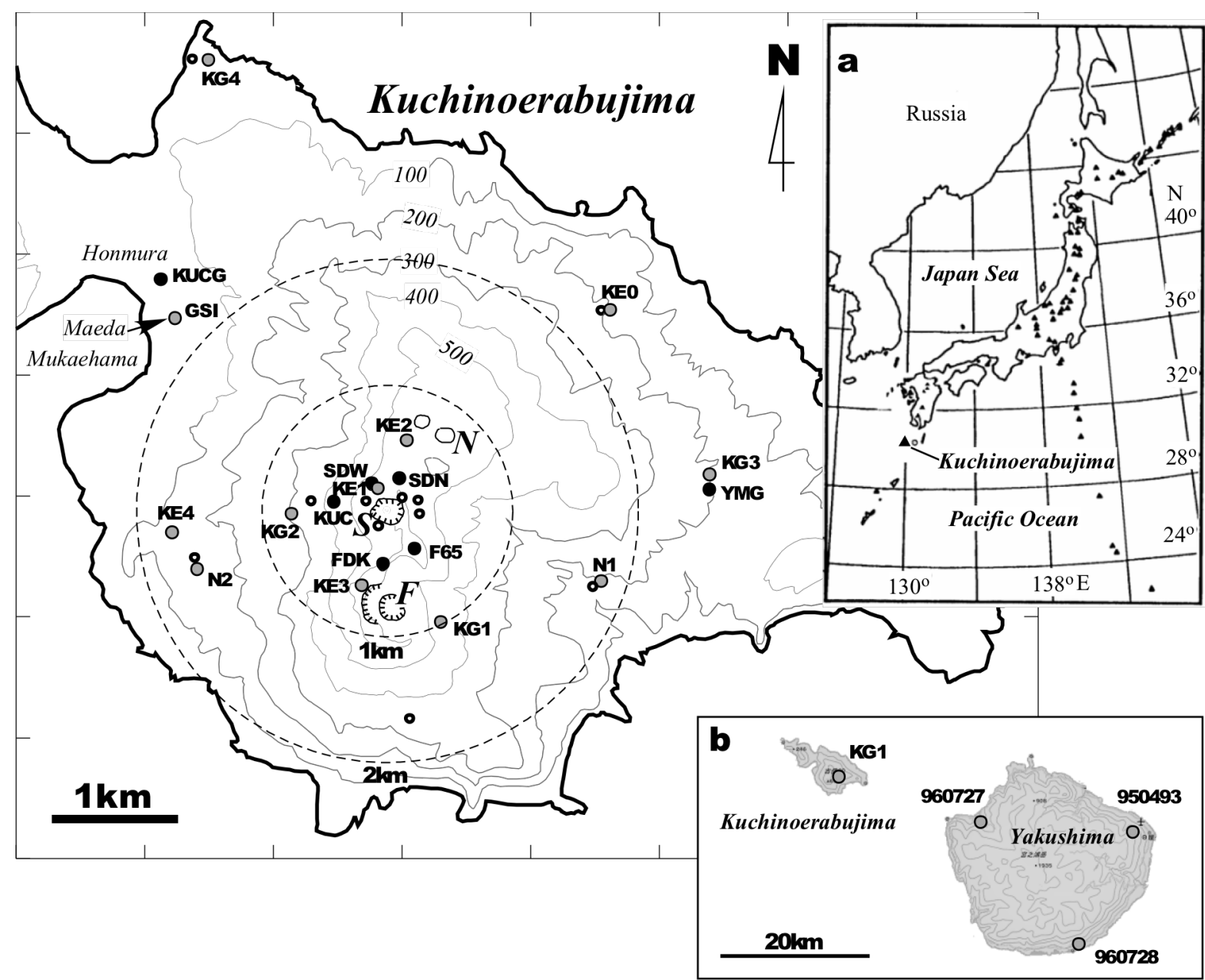

Fig. 1. Locations of stations containing seismometers, tiltmeters, and GNSS receivers near Kuchinoerabujima Volcano. Black dots and open circles indicate seismic stations and benchmarks for the GNSS campaign of Kyoto University. A tiltmeter is installed beside station SDN. Gray dots show stations belonging to JMA (names starting with KE and KG), GSI, NIED (names starting with N). $N, \mathrm{~S}$ and $F$ indicate Noike, Shindake and Furudake craters, respectively. a: Index map of Kuchinoerabujima, b: location of GNSS stations in Kuchinoerabujima and Yakushima Islands.

In December 1991, Kyoto University began continuously monitoring Kuchinoerabujima Volcano using a short-period seismometer. The monitoring system has since been expanded by integrating seismometers, a tiltmeter, Global Navigation Satellite System (GNSS) receivers, and proton magnetometers around Shindake crater and its flanks. Figure 1 shows the locations of the seismometers, tiltmeter, and GNSS receivers implemented before the 2014 eruption. Seismometers were installed around Shindake crater (two short-period seismometers with a period of $1 \mathrm{~s}$ at stations KUC and F65 and three broadband seismometers with periods of up to $50 \mathrm{~s}$ at stations SDW, SDN, and FDK) and two short-period seismometers were installed on the western (station KUCG) and northeastern (station YMG) flanks. A tiltmeter (Type 701-2, Applied Geomechanics) was installed at station SDN, $0.2 \mathrm{~km}$ northeast of the center of Shindake crater. Continuous GNSS observation has been performed since 2004 at the northwestern rim of Shindake crater (station SDW) and northwest of Furudake crater (station FDK) in collaboration with the Geological Survey of Japan. The GNSS receiver is a single-frequency receiver (MG2110, Furuno). To correct for the 
dependence of the vertical displacement on the vapor in the atmosphere, the meteorologically observed atmospheric temperature and humidity were included in the analysis (Saito and Iguchi, 2006). To expand the coverage of the GNSS observation, benchmarks for the GNSS campaign were defined for six sites around the crater and six sites on the flank (Fig. 1). JMA has installed five seismic and three GNSS stations, one of which is an integrated station at the northern part of the volcano. The National Research Institute for Earth Science and Disaster Resilience (NIED) operate two integrated stations on the southwestern and southeastern flanks. The GNSS station at the village of Maeda is a GEONET station operated by the Geospatial Information Authority of Japan (GSI), and the nearest GEONET station is located in Nagata, Yakushima.

Unfortunately, all the instruments near Shindake crater were destroyed by the 2014 eruption, and only stations located farther than $1 \mathrm{~km}$ from the crater were operational to monitor the volcanic activity before the 2015 eruption.

\section{Long-term precursor to the 2014 eruption}
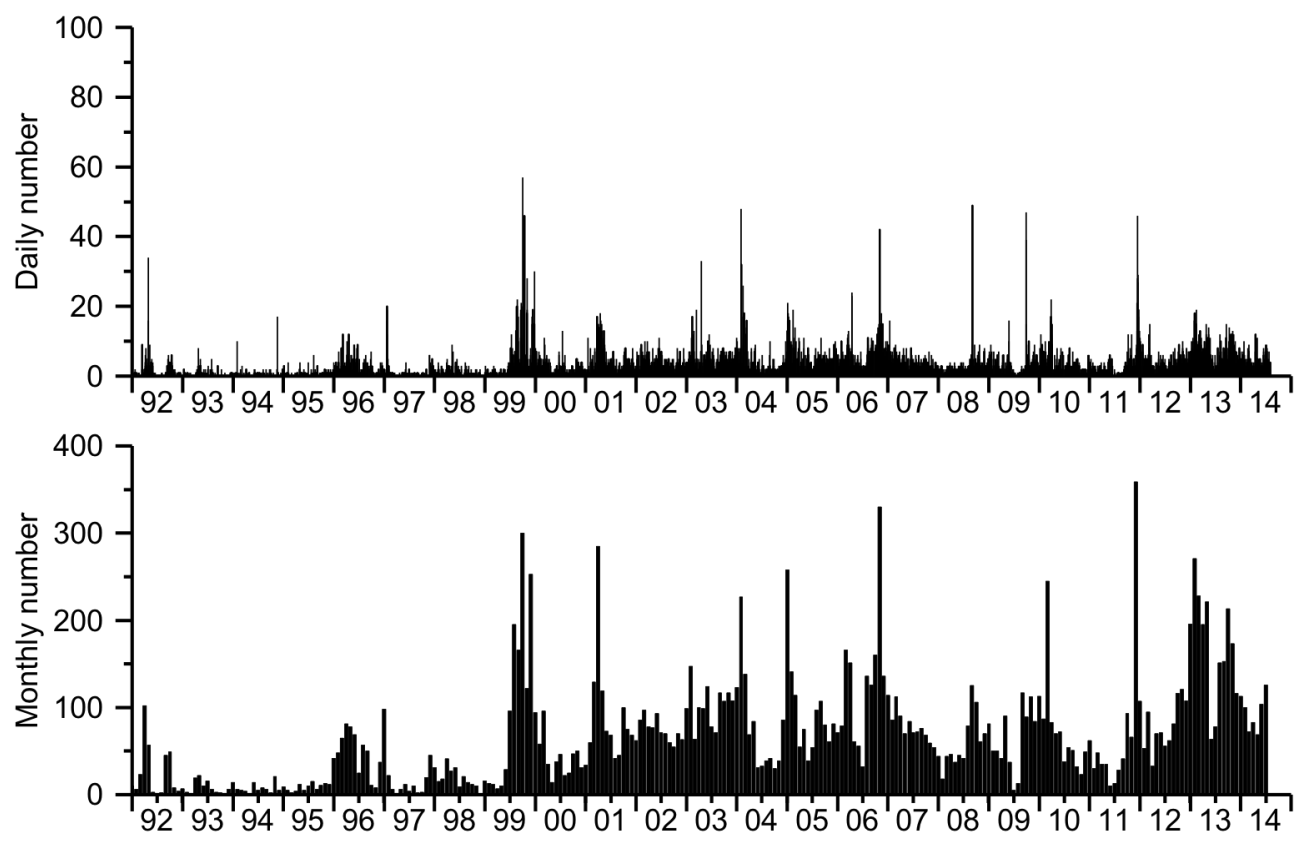

Fig. 2. Daily (top) and monthly (bottom) numbers of detected volcanic earthquakes of Kuchinoerabujima during the period from January 1, 1992 to August 3, 2014. Volcanic earthquakes with a maximum amplitude exceeding $10 \mathrm{micro} \mathrm{m} / \mathrm{s}$ at station KUC are classified as events.

Figure 2 shows the numbers of volcanic earthquakes detected daily and monthly at station KUC. The seismicity was relatively low before 1999 except during the period from March to June 1996; however, the seismicity suddenly increased on July 11, 1999, and the high level of seismicity continued until December 1999, attaining a monthly peak of 300 detected volcanic earthquakes in October 1999. The increase in seismicity in 1999 was not a single burst, and further increases in seismicity occurred in April 2001; February 2004; January 2005; March, April, October, and November 2006; September 2008; March 2010; December 2011; and December 2013. Large numbers of daily detected earthquakes show bursts of volcanic earthquakes, and the daily detections exceeded 20 events/day in April 2003, February 2004, January 2005, April and November 2006, September 2008, September 2009, March 2010, and December 2011. The 
occurrence rate of volcanic earthquakes before June 1999 was only 0.63 events/day; however, it remained at 3.01 events/day after July 1999.

Most volcanic earthquakes occurring at Kuchinoerabujima are high-frequency events dominated by frequencies greater than $10 \mathrm{~Hz}$. The hypocenters are concentrated at depths of less than $500 \mathrm{~m}$ beneath Shindake crater. The focal mechanism of the events is a normal fault striking in the NNE-SSW direction, and the strike direction coincides well with the alignment of the central cones of Noike, Shindake, and Furudake Volcanoes (Triastuty et al., 2009). Such high-frequency events have been classified as shallow, small-scale volcano tectonic (VT) earthquakes.

Increases in seismicity were accompanied by ground deformation near Shindake crater. Figure 3 shows the daily displacement of station SDW, which is located at the northwestern rim of the crater, during the period from April 2004 to one day before the 2014 eruption. The station moved northwestward and upward, indicating movement outward from the center of the crater. Campaign measurements have been repeated at 12 benchmarks near the crater and on the flanks of the volcano since 1995 . The vectors of the cumulative horizontal displacements are shown in Fig. 4. All the displacement vectors at the six benchmarks around the crater indicate movement outward from the center of the crater. In contrast, all the vectors on the flanks show minor fluctuations. This indicates that a pressure source may be located at a small depth beneath the crater. Based on the assumption that this source was a Mogi source (Mogi, 1958), it was calculated to be located at a depth of 100-200 m beneath Shindake crater (Iguchi et al., 2007). Therefore, movements upward and outward from the crater at station SDW indicate the inflation of the pressure source at a small depth beneath the crater.

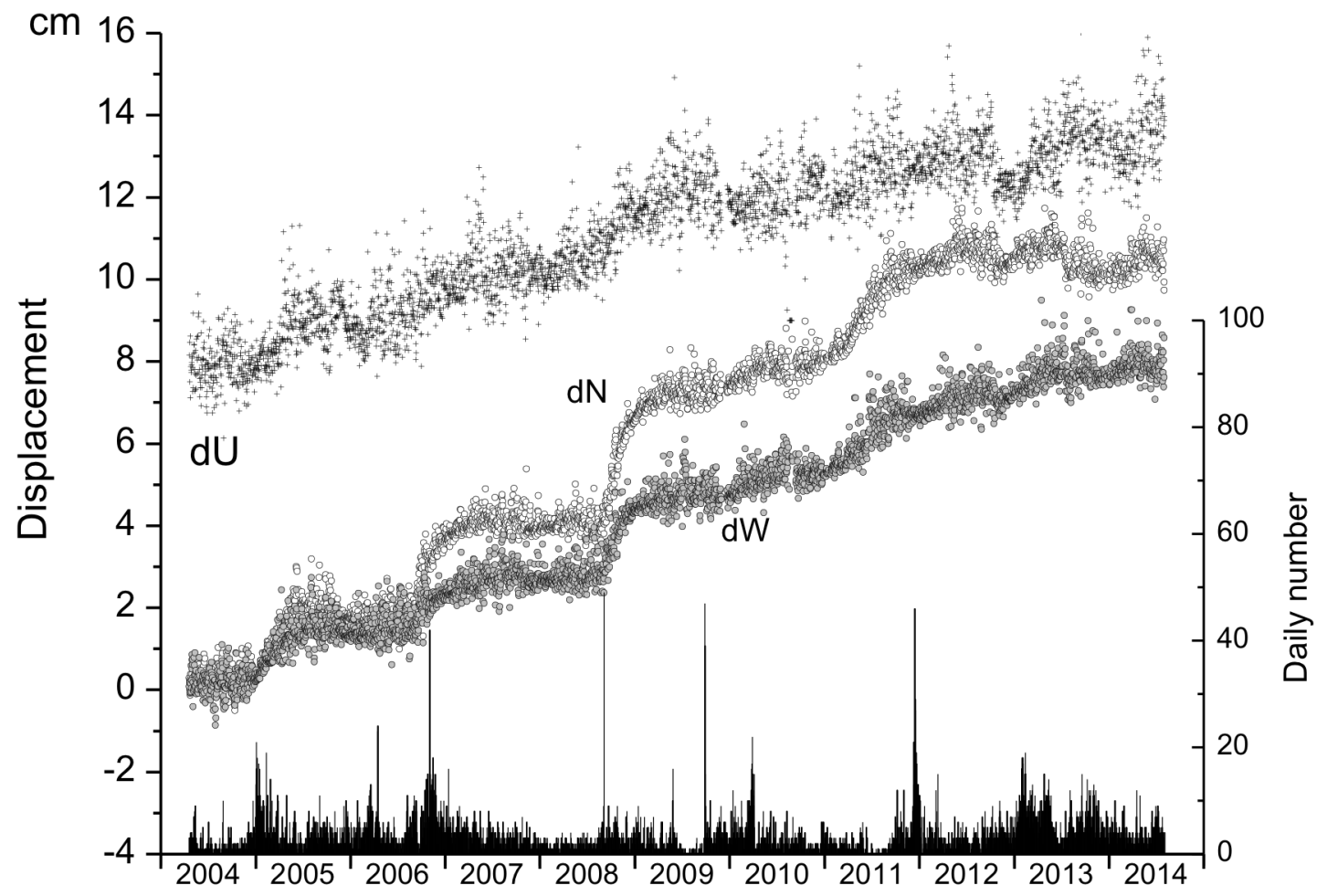

Fig. 3. Daily displacements of station SDW obtained by GNSS measurements during the period from April 2004 to August 2014. The daily numbers of detected volcanic earthquakes are shown at the bottom. 


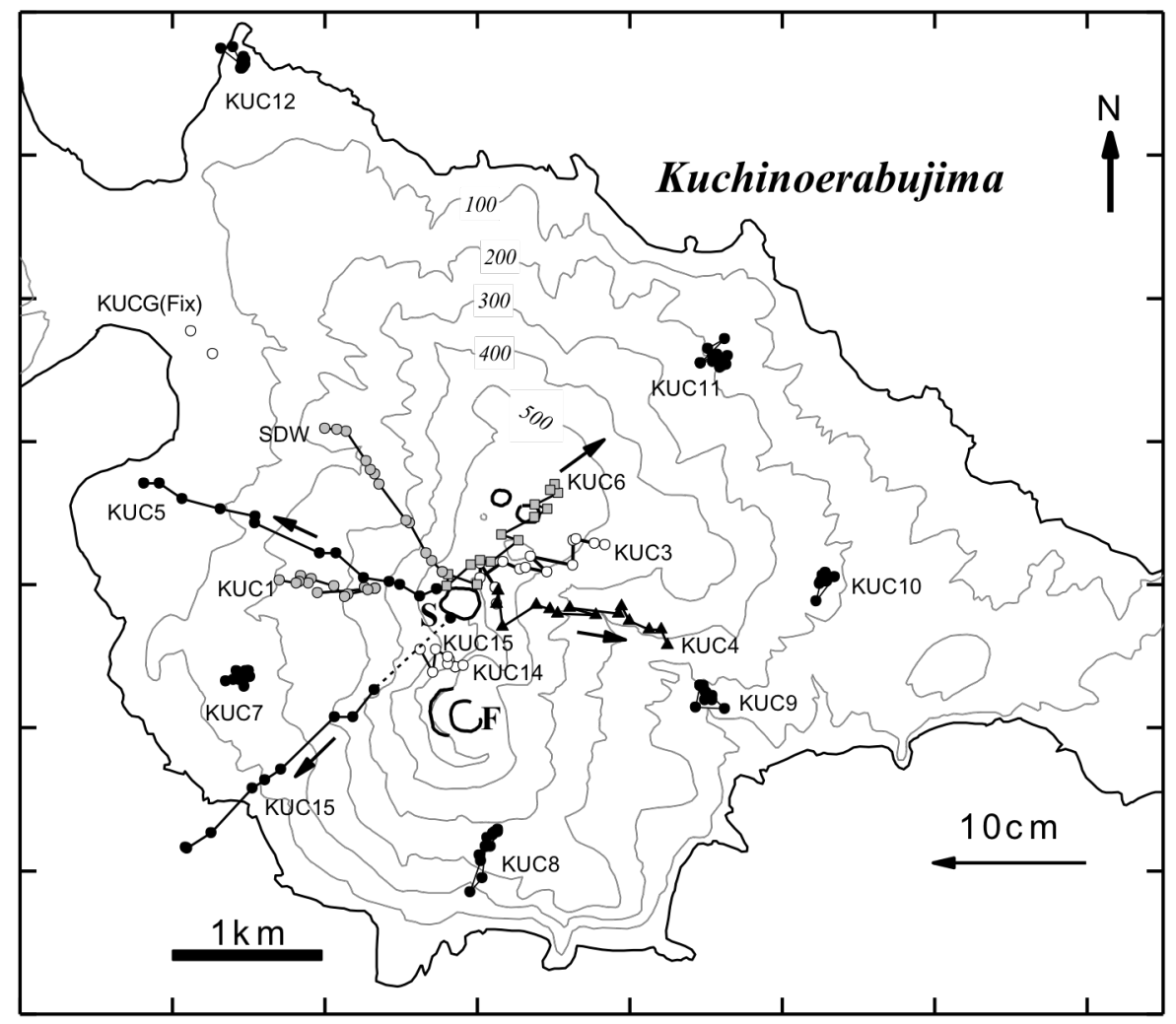

Fig. 4. Displacements of benchmarks obtained by GNSS campaign measurements during the period from 1995 to 2014.

The displacement pattern at station SDW shows repeated rapid inflation. Four rapid inflation events have occurred since 2004: January to May 2005, September 2006 to February 2007, September 2008 to April 2009, and January to October 2011. The rapid inflation events were similarly associated with increases in seismicity in 2004, 2006, and 2008 (Fig. 3). Station SDW began to move rapidly northwestward in September 2006, and the movement rate gradually decreased until it reached zero in February 2007. The daily number of detected volcanic earthquakes gradually increased from September 2006 and reached a maximum of 50 events/day on October 14. Similarly, the inflation event during the period from September 2008 to February 2009 shows a rapid increase in seismicity on September 15, 2008.

The repeated coseismic inflation events were accompanied by increases in geothermal activity. The continuous observation of the total geomagnetic force showed accumulation of heat beneath Shindake crater and revealed that the heat accumulation rate increased with the inflation event (Kanda et al., 2010). A weak fumarole was first detected at the crater bottom in April 2003, and its strength gradually increased. During the third inflation event in 2008, new fumarolic activity appeared at the south wall of the crater in October, and the plume grew until its elevation reached levels ranging from 200 to $500 \mathrm{~m}$. After the inflation event during the period from September 2008 to February 2009, the correspondence between seismicity and inflation decreased. VT earthquakes of Kuchinoerabujima Volcano are generated by rock fracturing as a result of the intrusion of hydrothermal fluid (Triastuty et al., 2009). The fracture of the rock beneath the crater progresses as a result of repeated bursts of VT earthquakes caused by the intrusion of fluid, and the new intrusion of hydrothermal fluid may not effectively induce such fracture (Saito et al., 2015).

Historical eruptions of Kuchinoerabujima Volcano have occurred at Shindake crater or the fissure east of the crater. Hypocenters of volcanic earthquakes are concentrated at depths of less than $500 \mathrm{~m}$ beneath 
Shindake crater, and sources of inflation deformation and changes in the total geomagnetic force are located in the hypocenter zone. The precursory activity detected by multiparameter observation occurred at Shindake crater, not along the eastern fissure. It was inferred that a subsequent eruption would occur at Shindake crater. The eruptions at the crater, such as those in 1931, 1933, and 1966, were larger than the eruptions at the fissure in 1945 and 1980. It was inferred that a future eruption would occur at Shindake and that the area suffering damage as a result of the eruptions would extend to the flanks of the volcano.

\section{Short-term activity before the 2014 eruption}

The seismicity of a volcanic earthquake increases before the occurrence of eruptions. Recent high-sensitivity observations near craters can be used to detect precursory signals even in phreatic eruptions. The seismicity of VT earthquakes increased two weeks before the 2014 eruption at Ontake Volcano (Kato et al., 2015). Such increases in seismicity were also detected before the 2007 eruption of this volcano (Nakamichi et al., 2009) and before the phreatic eruption of Tongariro Volcano in New Zealand in 2012 (Hurst et al., 2014). In contrast to the increase in seismicity prior to the phreatic eruptions, Kuchinoerabujima did not show short-term increases in the seismicity. The daily numbers of volcanic earthquakes at Kuchinoerabujima Volcano for seven months before the 2014 eruption are shown in Fig. 5. In 2014, fewer than 10 earthquakes occurred daily, and no sudden increase in seismicity was detected before the 2014 eruption, unlike in the case of Ontake and Tongariro Volcanoes.

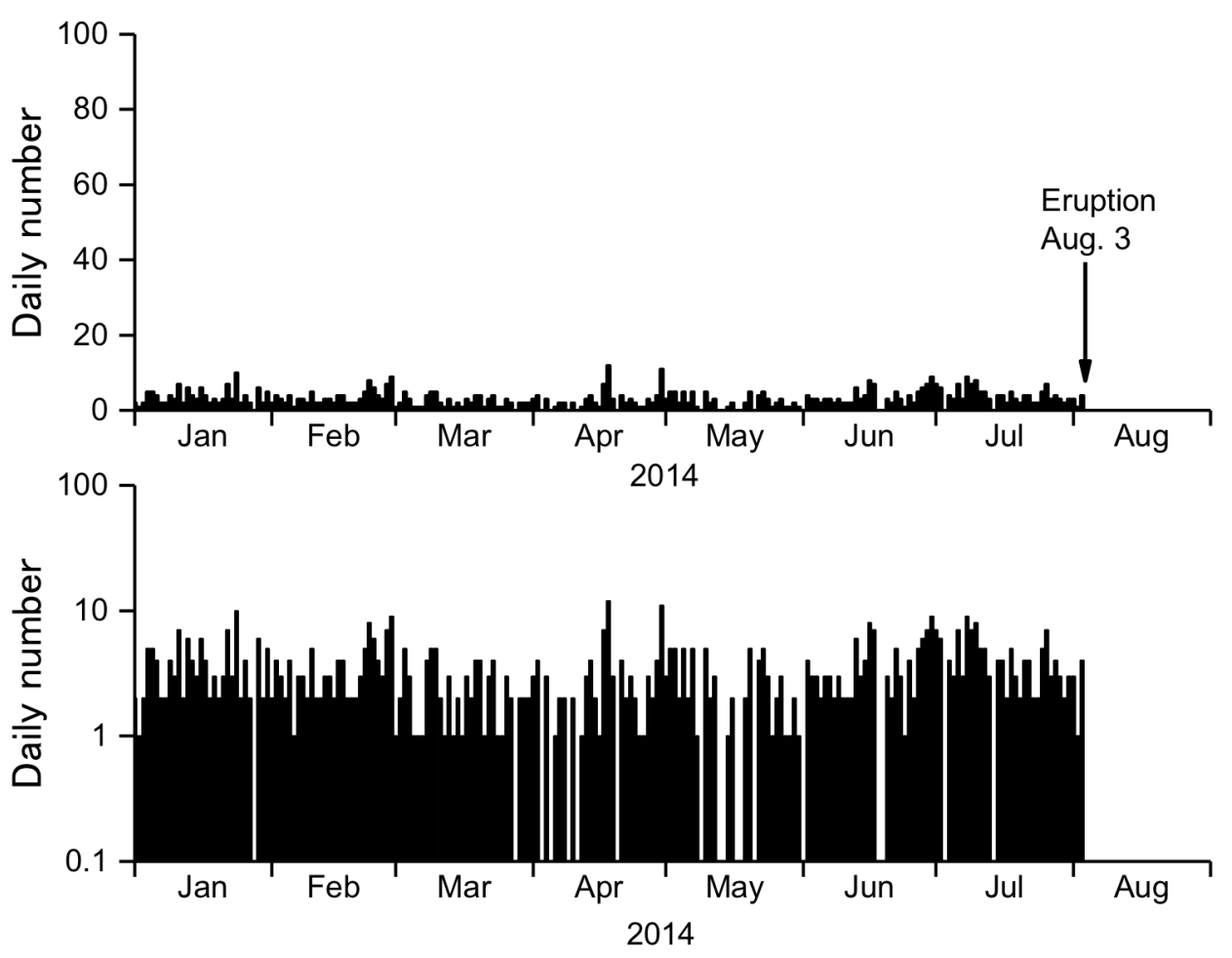

Fig. 5. Daily number of detected volcanic earthquakes at Kuchinoerabujima Volcano recorded for seven months before the 2014 eruption. The daily numbers are shown on linear- (top) and log- (bottom) scale plots; the log-scale plot more clearly depicts minor changes in the seismicity.

JMA reported that the eruption occurred at approximately 12:24 on August 3, 2014; this report was based solely on the occurrence of volcanic tremors because visual observation of the summit of Shindake 
was obstructed by clouds. The only significant phenomenon preceding the eruption was a tilt change that began one hour earlier. Figure 6 shows the tilt record obtained at station SDN, which is $200 \mathrm{~m}$ northeast of the center of Shindake crater. The crater side began to gradually tilt upward at approximately 11:00, and the change in the tilt accelerated at 12:00. The upward tilt vector coincides with the direction to the center of the crater. The change in the tilt amounted to a total of 10 micro radian by the start of the eruption.

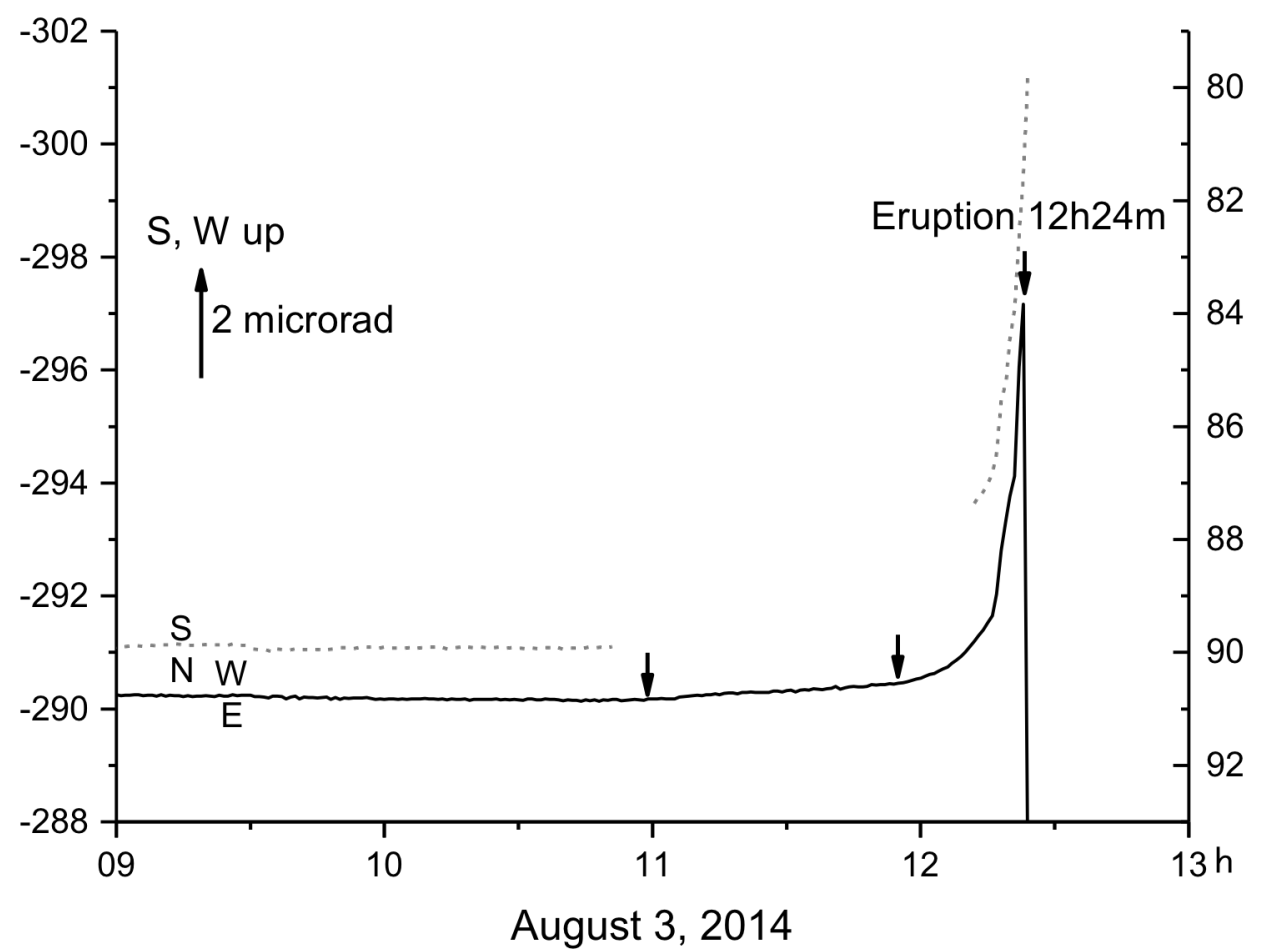

Fig. 6. Change in the upward tilt of the crater side immediately before the 2014 eruption, as recorded at station SDN. The black and dashed gray curves represent the east-west and north-south components of the tilt, respectively. The upward tilt began to increase at 11:00, and the change accelerated at 12:00 at an unusual rate, which had not been recorded, as shown by the arrows along the curve. Missing plots in the north-south component from 10:52 to 12:11 were caused by irregular motions.

\section{Precursory activity prior to the 2015 eruption}

The 2014 eruption was followed by an eruption on May 29, 2015. The precursory phenomena of the 2015 eruption progressed over five stages: (1) an increase in the discharge rate of $\mathrm{SO}_{2}$ gas, (2) the inflation of the volcano, (3) an increase in seismicity, (4) an increase in geothermal activity, and (5) an increase in seismicity that included a felt earthquake. Records of the daily number of volcanic earthquakes, the change in the slope distance, and the $\mathrm{SO}_{2}$ discharge rate are shown in Fig. 7. After the eruption on August 3, 2014, the discharge rate of $\mathrm{SO}_{2}$ gas gradually increased from 300 to 700 tons/day and increased rapidly in early December 2014 . The $\mathrm{SO}_{2}$ discharge rate showed a high level of 2000-3000 tons/day with a large fluctuation (Mori et al., 2017). The discharge rate attained a level equal to that associated with frequent magmatic eruptions at Sakurajima. 


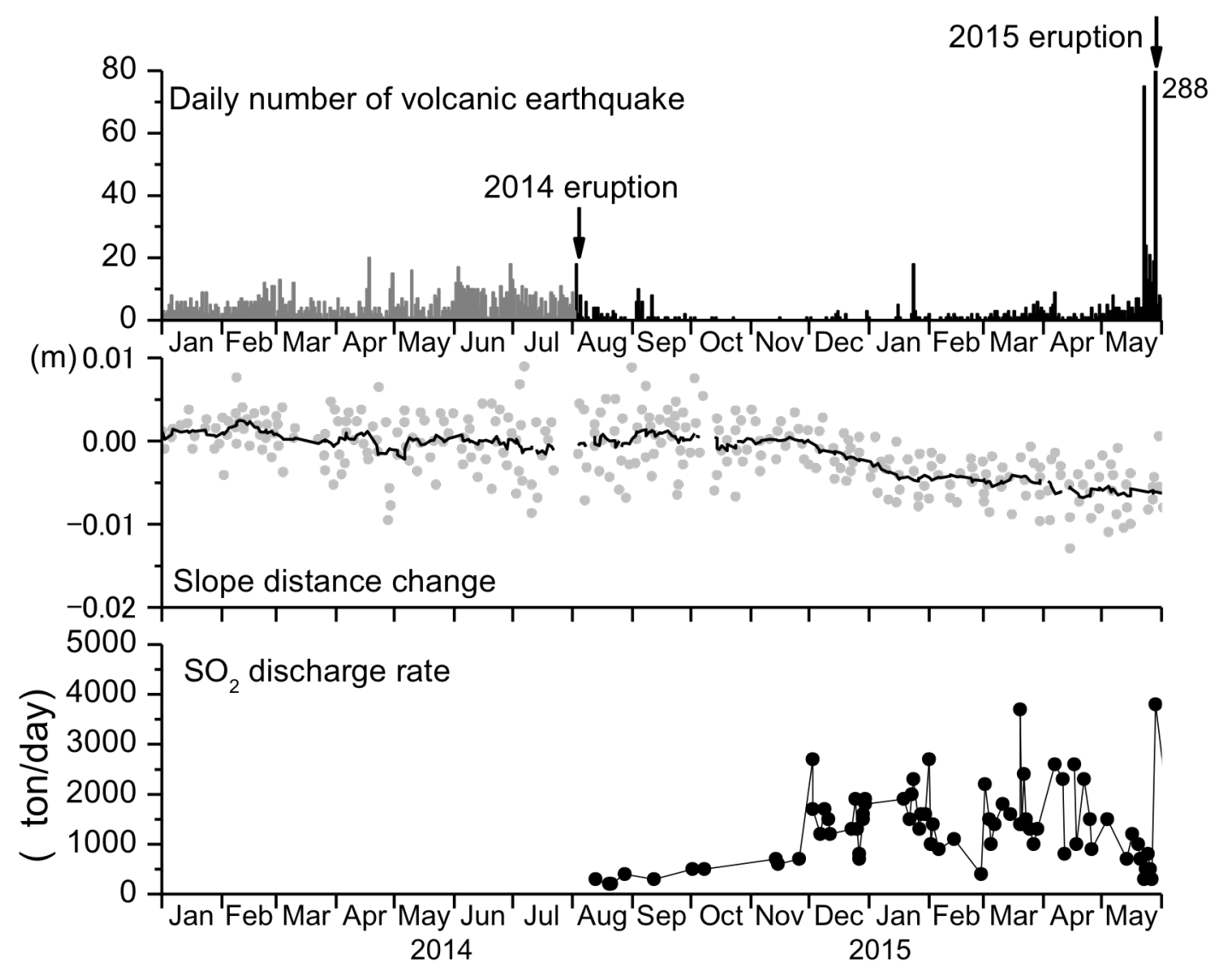

Fig. 7. Daily numbers of volcanic earthquakes (top), change in the slope distance (middle), and the discharge rate of $\mathrm{SO}_{2}$ gas (bottom) during the period from January 1, 2014, to May 31, 2015. The daily numbers were obtained by JMA. The slope distance was measured between station KG1in Kuchinoerabujima, and GEONET station Kamiyaku2 (960727) in Yakushima (locations shown in Fig. 1). The $\mathrm{SO}_{2}$ discharge rate was measured using the differential optical absorption spectroscopy (DOAS) traverse method on the volcano or by boat (Mori et al., 2017).

In accordance with the increase in the $\mathrm{SO}_{2}$ discharge rate, the ground inflation of the volcano was detected from December 2014 to January 2015, as indicated by the reduction of the slope distance between Nanakama station in Kuchinoerabujima and Kamiyaku2 station in Yakushima obtained by the GNSS continuous observation conducted by JMA and the records of the GEONET station of GSI. The reduction in the slope distance between Kuchinoerabujima and Yakushima indicates the inflation of the volcano. Precise leveling has been conducted on the western flank since 1996, and the vertical displacement of the relative upward movement of the crater side of Shindake was first detected during the period from August 2014 to March 2015 (Yamamoto et al., 2017). The vertical displacement supports the inflation of Shindake.

The inflation of the volcano induced an increase in the seismicity. Few volcanic earthquakes occurred in October and November 2014; however, the daily number began to gradually increase in December 2014 (Fig. 7), and a noteworthy earthquake (M2.6) occurred on January 24, 2014 at a depth of 4 $\mathrm{km}$ on the western flank of Shindake. JMA conducted repeated campaign measurements of the ground surface temperature using an infrared scanner and detected an increase in the temperature near the crater in February 2015. The high-sensitivity camera used by JMA captured volcanic glow above Shindake crater on the night of March 24, 2015 (Japan Meteorological Agency, 2015). The temperature on the ground near 
Shindake remained high until the occurrence of the 2015 eruption.

The seismicity of volcanic earthquakes increased at the end of April and again on May 19. A volcanic earthquake (M2.3) occurred at a depth of $2 \mathrm{~km}$ on the western flank and was felt in the village of Honmura. The seismicity after May 19 included a long-period event and a monochromatic event in addition to VT earthquakes. Higher-level seismicity continued until the occurrence of the eruption on May 29 (Ohminato et al., 2017). In contrast, the $\mathrm{SO}_{2}$ discharge rate decreased to several hundreds of tons per day several days before the eruption (Mori et al., 2017).

\section{Comparison of the precursory phenomena prior to the 2014 and 2015 eruptions}

The precursory phenomena of the 2015 eruption were compared with those of the 2014 eruption, as shown in Table 1. The seismicity of volcanic earthquakes at Kuchinoerabujima Volcano was dominated by shallow VT earthquakes concentrated beneath Shindake crater (Triastuty et al., 2009). The seismicity began to increase in July 1999 and was concentrated at a small depth beneath Shindake crater before the 2014 eruption. No VT earthquakes with magnitudes exceeding M2 occurred during the period from July 1999 to July 2014 leading up to the 2014 eruption. However, large VT events with magnitudes of M2.6 and M2.3 occurred on January 24 and May 23, 2015, respectively, prior to the 2015 eruption. These VT earthquakes were located at depths of 4 and $2 \mathrm{~km}$ beneath the western flank, respectively, and accompanied shallow VT events beneath Shindake crater. The seismicity intensified before the 2015 eruption, and the hypocenters were more widely distributed in the 2015 eruption than in the 2014 eruption.

Table 1. Comparison of precursory phenomena of the 2014 and 2015 eruptions

\begin{tabular}{|c|c|c|}
\hline & 2014 eruption & 2015 eruption \\
\hline Duration & 15 years & 10 months \\
\hline Seismicity & $\begin{array}{l}\text { Intermittent earthquake } \quad \text { swarm } \\
\text { occurred at a small depth beneath } \\
\text { Shindake crater. } \\
\text { No felt earthquake occurred. }\end{array}$ & $\begin{array}{l}\text { VT earthquakes occurred on the west } \\
\text { flank at a depth of } 4 \mathrm{~km} \text { (M2.6) on } \\
\text { January } 24,2015 \text {, and at a depth of } 2 \mathrm{~km} \\
\text { (M2.3) on May 23, 2015. These were } \\
\text { felt at villages } 2.5-3.5 \mathrm{~km} \text { west of the } \\
\text { crater. }\end{array}$ \\
\hline $\begin{array}{l}\text { Ground } \\
\text { deformation }\end{array}$ & $\begin{array}{l}\text { Displacement of less than } 30 \mathrm{~cm} \\
\text { occurred near Shindake crater. The } \\
\text { deformation was concentrated around } \\
\text { the crater, and no significant } \\
\text { deformation was detected at the } \\
\text { flanks. }\end{array}$ & $\begin{array}{l}\text { All the instruments near the crater were } \\
\text { damaged by the } 2014 \text { eruption. } \\
\text { Ground inflation and uplifting of the } \\
\text { crater side were detected by GNSS and } \\
\text { precise leveling on the flanks of the } \\
\text { volcano. }\end{array}$ \\
\hline $\begin{array}{l}\text { Volcanic gas } \\
\left(\mathrm{SO}_{2}\right)\end{array}$ & Maximum 300 tons/day (2008-2009) & Maximum 4000 tons/day \\
\hline $\begin{array}{l}\text { Geothermal } \\
\text { activity }\end{array}$ & $\begin{array}{l}\text { Gradual increase in geothermal } \\
\text { activity since } 2003 \text {. } \\
\text { No volcanic glow was detected. }\end{array}$ & $\begin{array}{l}\text { Increase in geothermal activity from } \\
\text { February } 2015 \text {. Volcanic glow has been } \\
\text { detected since March } 24,2015 \text {. }\end{array}$ \\
\hline
\end{tabular}

Ground deformation was concentrated around Shindake crater before the 2014 eruption. No significant displacement was detected on the flanks of Shindake. Applying the Mogi model (Mogi, 1958) to the ground deformation around the crater during the period from 2001 to 2014 (Fig. 3) yielded a pressure source at a depth of $0.5 \mathrm{~km}$ beneath the crater, and the volume of the pressure source was estimated to have 
increased by $5 \times 10^{5} \mathrm{~m}^{3}$. Although no observations could be conducted around the crater because of the destruction caused by the 2014 eruption and the restricted zone defined near the crater, displacements on the flanks occurring before the 2015 eruption were first detected by precise leveling (Yamamoto et al., 2017) and GNSS campaigns. The increase in volume of the pressure source was estimated to be $3 \times 10^{6} \mathrm{~m}^{3}$ (Yamamoto et al., 2017), which is much larger than the sum of the increases in volume before the 2014 eruption.

Geothermal activity gradually increased before the 2014 eruption, as demonstrated by the total geomagnetic force (Kanda et al., 2010), and fumaroles appeared at the crater bottom in 2003 and the south wall in 2008. However, no volcanic glow was detected before the 2014 eruption. Visible volcanic glow was first detected by JMA on March 24, 2015. The temperature of the ground surface before the 2015 eruption was higher than that during the precursory activity of the 2014 eruption.

The $\mathrm{SO}_{2}$ discharge rate was first measured by a compact ultraviolet spectrometer system (COMPUSS) in December 2006, after a detected increase in seismicity in November 2006 (Mori, 2007). The discharge rate was only 40 tons/day, and it increased to 200 tons/day after the appearance of new fumaroles at the south wall of Shindake crater in October 2008 (Mori et al., 2009). This is the largest discharge rate obtained before the 2014 eruption. However, the discharge rate before the 2015 eruption was much larger than that before the 2014 eruption. The discharge rate dramatically increased to 2700 tons/day at the beginning of December 2014 and fluctuated within a range of 700-3700 tons/day (Mori et al., 2017). Considering the seismicity, ground deformation, geothermal activity, and volcanic gas discharge rate, it was concluded that the intensity of the precursory activity of the 2015 eruption was much greater than that of the 2014 eruption.

\section{Felt VT earthquake on 23 May, 2015 as a trigger to upgrade VAL to 5}

In order to start VAL in December 2007, JMA and the local government of Yakushima town determined preliminary restricted areas within a radius of $1 \mathrm{~km}$ from Shindake crater for VAL of 2 and $2 \mathrm{~km}$ for VAL of 3. JMA upgraded the VAL from 1 to 3 and restricted access to the area within a radius of $2 \mathrm{~km}$ from Shindake crater after the eruption on August 3,2014, because pyroclastic surges approached the criteria of $2 \mathrm{~km}$ from the crater. Mukaehama area was also restricted on August 7 as re-informed VAL 3 by JMA. The restricted area adjoining Maeda is $2-2.5 \mathrm{~km}$ from the crater. Upgrading the VAL to 3 implies that the occurrence of an eruption larger than the 2014 eruption would result in a VAL upgrade from 3 to 5 . After the eruption on May 29, 2015, JMA issued a VAL 5 warning, which indicates the likelihood of "eruption or imminent eruption causing significant damage to residential areas." As described in the previous section, the precursory phenomena of the 2015 eruption were more intense than the gradual increase in volcanic activity detected prior to the 2014 eruption. These more active precursors indicated the likelihood of an imminent eruption that would be larger than the 2014 eruption, leading to the upgrading of the VAL. This section discusses the proper criteria for the upgrading of the VAL before the occurrence of the 2015 eruption.

After the eruption on August 3, 2014, many observation parameters indicated that there had been an increase in volcanic activity. The first such parameter is the increase in the discharge rate of $\mathrm{SO}_{2}$ gas, which increased dramatically to 3000 tons/day at the beginning of December 2014 and remained high with large fluctuations until April 2015. Simultaneously, the inflation of the volcano began and was followed by a gradual increase in the seismicity of volcanic earthquakes. During the progress of the volcanic activity, the high-sensitivity monitoring camera used by the JMA captured volcanic glow on Shindake crater on March 24, 2015. The most intense precursory phenomenon was the felt earthquake on 23 May, 2015. The felt earthquake could be the only trigger to upgrade VAL from 3 to 5. One of the authors, Iguchi, recommended that JMA upgrade the VAL to 5 one hour after the felt earthquake, because felt earthquakes had occurred immediately before some historic eruptions. 
Table 2. Volcanic eruptions in Japan since 1900 prompting the evacuation of residents

\begin{tabular}{|c|c|c|c|}
\hline Year & Volcano & $\begin{array}{l}\text { Precursory } \\
\text { seismicity }\end{array}$ & Remarks \\
\hline 1902 & Izu-Torishima & Unknown & Phreatic eruption, all residents (125) dead \\
\hline 1903 & Iwo-Torishima & Unknown & $\begin{array}{l}\text { Phreatic eruption, evacuation from the } \\
\text { island }\end{array}$ \\
\hline 1910 & Mt. Usu & $\begin{array}{l}\text { Many felt } \\
\text { earthquakes }\end{array}$ & \\
\hline 1914 & Sakurajima & $\begin{array}{l}\text { Many felt } \\
\text { earthquakes }\end{array}$ & $\begin{array}{l}\text { All residents }(>21,000) \text { evacuated from the } \\
\text { island, } 58 \text { dead, } 6,000 \text { relocated from } \\
\text { the island }\end{array}$ \\
\hline 1926 & Mt. Tokachi & Felt earthquake & Mud flow, 144 dead \\
\hline 1929 & $\begin{array}{l}\text { Hokkaido- } \\
\text { Komagatake }\end{array}$ & Felt earthquake & Plinean eruption \\
\hline 1933 & Kuchinoerabujima & Unknown & 34 casualties \\
\hline 1939 & Izu-Torishima & Unknown & \\
\hline 1940 & Miyakejima & $\begin{array}{l}\text { Many felt } \\
\text { earthquakes }\end{array}$ & Lava flow, 11 dead \\
\hline $1944-1945$ & Mt. Usu & $\begin{array}{l}\text { Many felt } \\
\text { earthquakes }\end{array}$ & Lava dome formation (Showa Shinzan) \\
\hline 1946 & Sakurajima & Unfelt & Lava flow, 1 dead, 1 village buried \\
\hline 1962 & Mt. Tokachi & $\begin{array}{l}\text { Many felt } \\
\text { earthquakes }\end{array}$ & Plinean eruption \\
\hline $1977-1982$ & Mt. Usu & $\begin{array}{l}\text { Many felt } \\
\text { earthquakes }\end{array}$ & Plinean eruption at the summit \\
\hline 1983 & Miyakejima & Felt earthquake & Ako village buried by lava flow \\
\hline 1986 & Izu-Oshima & $\begin{array}{l}\text { Many felt } \\
\text { earthquakes }\end{array}$ & 11,000 evacuated from the island \\
\hline $1991-1995$ & Mt. Unzen & $\begin{array}{l}\text { Many felt } \\
\text { earthquakes }\end{array}$ & $\begin{array}{l}\text { Pyroclastic flow, } 43 \text { dead, } 11,000 \\
\text { evacuated }\end{array}$ \\
\hline 2000 & Mt. Usu & $\begin{array}{l}\text { Many felt } \\
\text { earthquakes }\end{array}$ & 16,000 evacuated \\
\hline 2000 & Miyakejima & $\begin{array}{l}\text { Many felt } \\
\text { earthquakes }\end{array}$ & $\begin{array}{l}\text { Volcanic gas, } 3500 \text { evacuated from the } \\
\text { island }\end{array}$ \\
\hline 2011 & Shinmoedake & Unfelt & $\begin{array}{l}1152 \text { evacuated, evacuation advisory by } \\
\text { local government, under VAL } 3\end{array}$ \\
\hline 2015 & Kuchinoerabujima & Felt earthquakes & 137 evacuated from the island, VAL 5 \\
\hline
\end{tabular}

The occurrence of felt earthquakes was reported prior to the eruptions that historically caused damage to the flank of Kuchinoerabujima Volcano. Some felt earthquakes occurred prior to an eruption occurring at 19:30 on April 2, 1931. The northwestern part of Shindake crater collapsed as a result of the eruption, and Mukaehama was damaged by the pyroclastic material ejected during the eruption. Sulfur miners felt the ground shaking at Shindake at 07:00, 10:00, 12:00, and 15:00, and ground motion was also felt on the flank of the volcano at 16:40 and 18:40 (Nakano, 1932; Tanakadate, 1938). An eruption on November 22, 1966 produced a volcanic ash cloud reaching an elevation of $5000 \mathrm{~m}$, and volcanic bombs from this eruption flew to a distance of $3 \mathrm{~km}$. Ground vibrations were felt at a village $2.5 \mathrm{~km}$ away from the crater 10 min before the eruption and near the summit a few minutes before (Kagoshima Local 
Meteorological Observatory and Yakushima Weather Station, 1967). It was inferred that the precursory seismicity of the 1931 and 1966 eruptions was higher than that of the 2015 eruption, which was preceded by only one felt earthquake six days before. However, the 1931 and 1966 eruptions occurred after a dormancy lasting approximately 20 years, in contrast to the 2015 eruption occurring only 10 months after the 2014 eruption. The top of the conduit was more tightly closed prior to the 1931 and 1966 eruptions than prior to the 2015 eruption.

The occurrence of felt earthquakes near volcanoes is a major factor in forecasting volcanic eruptions. Table 2 gives a list of volcanic eruptions occurring in Japan since 1900 that required the evacuation of residents from the areas surrounding the volcanoes. In this period, residents near volcanoes were evacuated as a result of 21 volcanic eruptions of 11 volcanoes. The largest number of evacuees was recorded after the 1914 Sakurajima eruption, and over 10,000 residents were evacuated as a result of the 1986 Izu-Oshima, 1991 Unzen, and 2000 Usu eruptions. Felt earthquakes occurred prior to 14 of the 21 eruptions listed in Table 2. Excluding the eruptions at Izu-Torishima and Iwo-Torishima and the 1933 Kuchinoerabujima eruption, the details of which are not well known, only two eruptions were not preceded by precursory felt earthquakes: the 1946 Sakurajima and 2011 Shinmoedake (Kirishima) eruptions. Felt earthquakes are not necessarily followed by volcanic eruptions; however, the occurrence of felt earthquakes can be considered a clear warning criterion when forecasting volcanic eruptions.

Only one felt earthquake occurred on May 23, 2015, and its seismic energy $\left(10^{8} \mathrm{~J}\right)$ was much smaller than those of the earthquakes preceding the other eruptions listed in Table 2. For example, the largest seismicity, which exceeded $10^{14} \mathrm{~J}$, was recorded before the 1914 Sakurajima eruption, and the seismicity prior to eruptions at Usu Volcano attained at the same level. However, the earthquake on May 23, 2015 at Kuchinoerabujima Volcano cannot be dismissed as one lone felt earthquake, because the felt earthquake occurred after progressive increases in activity demonstrated by changes in many parameters, as mentioned in the previous section. The felt earthquake was not a coincidental event to the eruption but was caused by a fracture in a shallow part of the volcano due to the intrusion of magma, which discharged a significant volume of volcanic gas and heat. The epicenter of the felt earthquake was located at a depth of $2 \mathrm{~km}$, shallower than that of the felt event on January 24, 2015, at a depth of $4 \mathrm{~km}$.

\section{Evaluation of post activity of the 2015 eruption}

The eruption on May 29, 2015, was followed by a vulcanian eruption on June 18; at this time, the summit area of Shindake was covered by cloud, and eruptive phenomena could not be visually observed. Many lapilli fell on the eastern flank of the volcano and reached a coastguard ship $9 \mathrm{~km}$ east of the volcano. Unlike the eruption on May 29, no traces of pyroclastic flow were detected by aerial observation after the eruption on June 18. Figure 8 shows the daily number of volcanic earthquakes and the discharge rate of $\mathrm{SO}_{2}$ gas. The daily number of volcanic earthquakes remained high at greater than 30 events/day until the middle of event/day in October. The decrease in seismicity was confirmed by near-crater seismic stations, which were installed by an unmanned aviation vehicle. The numbers of VT, long-period, and monochromatic earthquakes decreased to the same level as that before the precursory seismicity increase on May 19 (Ohminato et al., 2016; 2017). A high discharge rate of $\mathrm{SO}_{2}$ of 4000 tons/day was obtained immediately after the eruption on May 29; however, the rate showed a decreasing trend. The rate decreased to 200 tons/day at the end of August and was much smaller than that during the period December 2014 to May 2015 (Mori et al., 2017). However, significant depression of the volcano was not detected after the 2015 eruption by a precise leveling survey on the western flank of the volcano (Yamamoto et al., 2017) nor by the continuous GNSS observation by JMA and GEONET. This indicates that the inflation conditions were maintained after the 2015 eruption, although the seismicity and $\mathrm{SO}_{2}$ discharge rate decreased. It is interpreted that most of the magma was stored in the volcano before the 2015 eruption; however, the top of the conduit was not as pressurized before the 2015 eruption as during it. 
JMA did not determine alert zone clear in the VAL 5 warning issued immediately after the 2015 eruption. The alert zone was only described as a "residential area possibly suffering from pyroclastic flows". Due to an unrestricted alert zone on Kuchinoerabujima Island, the local government of Yakushima town issued an "Evacuation directive" to all villages on the island, and 137 residents, including visitors, were evacuated from the island to neighboring Yakushima by ferry. On October 21, 2015, JMA declared an alert zone within a distance of 2-2.5 km from Shindake crater under the VAL 5 warning after the 2015 eruption, considering the above-mentioned decrease in volcanic activity. The alert zone was actually reduced as a result of the information obtained on October 21; however, the alert zone was first defined in Kuchinoerabujima in the JMA's information, which declared an alert to residential areas only, which would possibly suffer pyroclastic flows immediately after the eruption. As a result, the local government released the evacuation order, and evacuees from villages further than $2.5 \mathrm{~km}$ away from the crater returned to these villages at the end of 2015, except Maeda, which is $2.2-2.5 \mathrm{~km}$ from the crater.

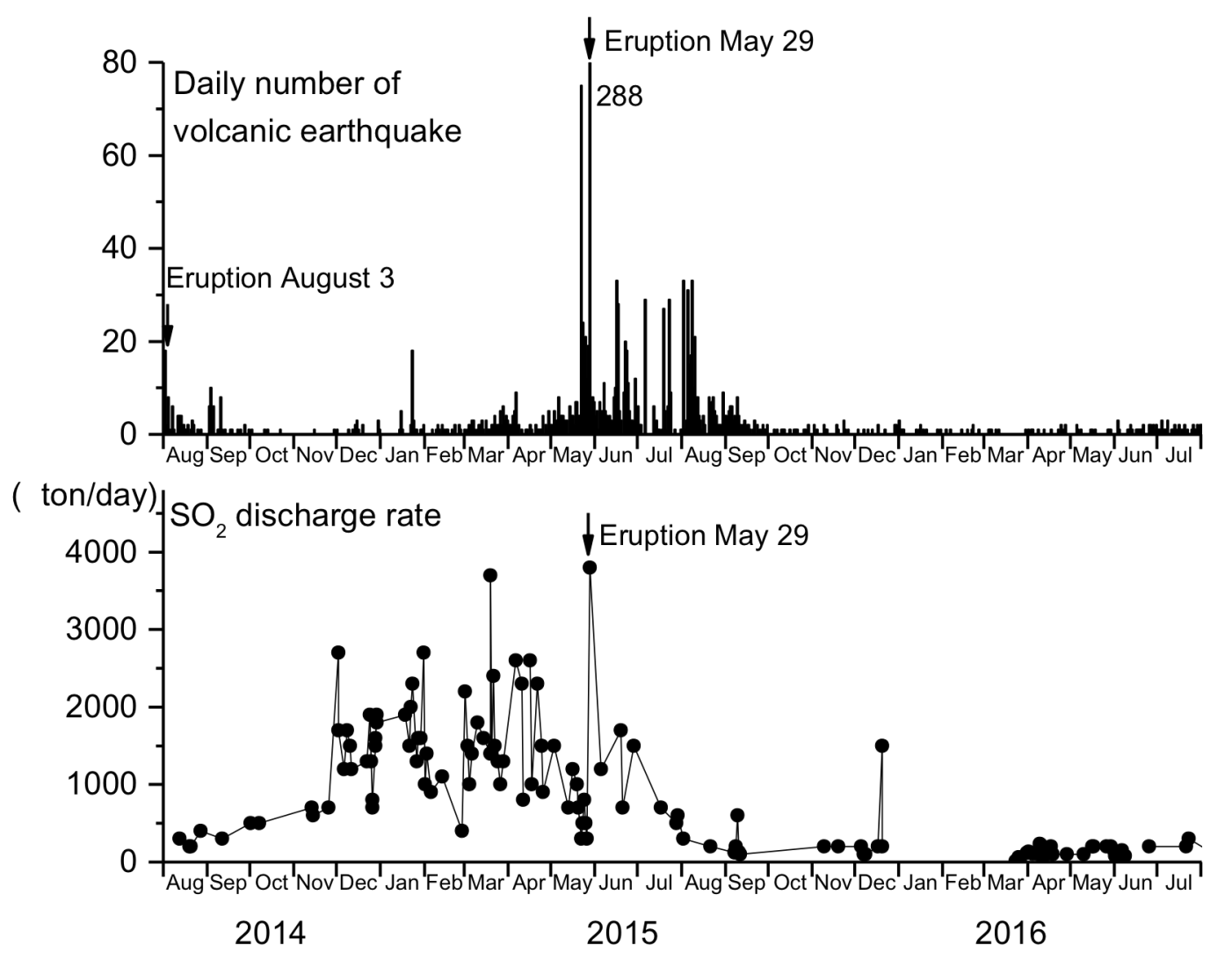

Fig. 8. Daily numbers of detected volcanic earthquakes (top) and discharge rate of $\mathrm{SO}_{2}$ gas (bottom) after the 2014 eruption on August 3. The daily numbers were obtained by JMA. The $\mathrm{SO}_{2}$ discharge rate was measured using the DOAS traverse method on the volcano or by boat (Mori et al., 2017).

Low seismicity with two or fewer daily volcanic earthquakes continued after October 2015, and the discharge rate of $\mathrm{SO}_{2}$ gas remained at 100 tons/day. In addition to the decrease in seismicity and discharge rate, the baseline beyond Shindake crater began to contract in January 2016. This suggests the contraction of the shallow part of the volcano due to the release of volcanic gas from the upper part of the conduit. On June 14, 2016, JMA downgraded the VAL from 5 to 3 within the alert zone $2 \mathrm{~km}$ from the crater. This indicates that all the villages were excluded from the alert zone. The downgrading of the VAL indicated that the evacuees from Maeda were able to return to their homes. 
However, a precise leveling survey on the western flank revealed the resumption of the uplift of the crater side during the period from March to June, 2016 (Yamamoto et al., 2017). The seismicity showed a slight increasing trend after June 2016. Additionally, the $\mathrm{SO}_{2}$ gas discharge rate of 100-200 tons/day at this time was still greater than that (30 tons/day) immediately before the 2014 eruption. Therefore, the present state of these parameters indicates that Kuchinoerabujima Volcano still has the potential to erupt again. The eruptions in 1931 were followed by eruptions during the period from December 1933 to January 1934, and after the 1966 eruption, eruptions successively occurred in 1968, 1969, 1972, 1973, 1974, 1976, and 1980.

\section{Discussion and Conclusions}

Prior to the 2014 eruption, many parameters indicated that volcanic activity had been increasing since July 1999; these parameters include repeated bursts of volcanic earthquakes, the inflation of the ground around Shindake crater, increases in geothermal activity as inferred from changes in the total geomagnetic force, and intensified fumarolic activity. JMA upgraded the VAL from 1 to 2 or from 2 to 3 after these bursts of volcanic earthquakes. After 2009, the parameters remained at high levels; however, no significant changes were detected until the onset of the 2014 eruption. Therefore, the VAL remained at 1 before the 2014 eruption.

Following the 2014 eruption, increases in the discharge rate of $\mathrm{SO}_{2}$ gas, ground deformation on the flanks, increases in the daily number of volcanic earthquakes, and the appearance of volcanic glow were successively detected before the 2015 eruption, which led to the evacuation of residents. Finally, seismicity increased significantly, including the felt earthquake (M2.3) occurring six days before the 2015 eruption. Ground deformation showed gradual inflation, and volcanic glow occurred as a result of a gradual increase in temperature. The measurement of the $\mathrm{SO}_{2}$ discharge rate strongly depends on weather conditions, and it is difficult to periodically obtain accurate measurement results. Considering the increasing pattern of these parameters, a sudden increase of seismicity is the most important parameter in deciding whether to upgrade the alert level and thus take disaster prevention steps, including the evacuation of residents. Therefore, the felt earthquake on May 23 could be considered an appropriate trigger to upgrade the VAL to 5 .

In the general operation of the VAL by JMA, the VAL was not upgraded to an appropriate level when no significant seismicity was detected, even though other precursory phenomena were recorded. Prior to the 2011 Shinmoedake eruption, inflation of the volcano was clearly detected by GNSS as an extension of the slope distance (Nakao et al., 2013); however, the VAL was upgraded from 2 to 3 only after the onset of the eruption. Conversely, in some previous cases, when an increase in seismicity has been detected, JMA has responded by upgrading the VAL (for example, the VAL was upgraded before the eruptions at Asama and Hakone Volcanoes in 2015 and upgraded to 2 at Shinmoedake in 2010), even if the upgrading of the VAL prior to the 2014 Ontake eruption with significant precursory seismicity was not well handled. A significant increase in seismicity, particularly accompanied by the occurrence of felt earthquakes, is the most important criterion in determining whether to upgrade the VAL, especially when supported by other parameters. In the case of the 2015 eruption of Kuchinoerabujima Volcano, the felt earthquake on May 23 as a trigger to upgrade the VAL to 5 was well supported by the progress of other parameters.

\section{Acknowledgement}

We would like to thank the staff of Sakurajima Volcano Research Center for their maintenance of the permanent observation system of Kuchinoerabujima Volcano. This work was supported by the Ministry of Education, Culture, Sports, Science and Technology (MEXT) of Japan under its Earthquake and Volcano Hazards Observation and Research Program and by MEXT KAKENHI Grant Number 15H05794. 


\section{References}

Geshi, N., Kobayashi, T., 2006. Volcanic structure and geology of Kuchinoerabujima Volcano, Bull. Volcanol. Soc. Japan, 51, 103-105.

Fujii, T., 2016. Present situation and issues of concern on the prediction of volcanic eruption in Japan, Bull. Volcanol. Soc. Jpn., 61, 211-223.

Hurst, T., Jolly, A.D., Sherburn, S., 2014. Precursory characteristics of the seismicity before the 6 August 2012 eruption of Tongariro Volcano, North Island, New Zealand, Jour. Volcanol. Geotherm. Res., 286, 294-302.

Iguchi, M., Saito, E., Tameguri, T., Triastuty, H., Yamazaki, T., 2007, Evaluation of volcanic activity of Kuchinoerabujima in 2006, Ann. Disast. Prev. Res. Inst., Kyoto Univ., 50B, 349-358.

Kagoshima Local Meteorological Observatory, Yakushima Weather Station, 1967. Explosive eruption at Shindake of Kuchinoerabujima Volcano on November 22, 1966, Fukuoka District Meteorological Observatory main report, 22, 79-98.

Kanda, W., Utsugi, M., Tanaka, Y., Hashimoto, T., Fujii, I., Hasenaka, T., Shigeno, N., 2010. A heating process of Kuchinoerabujima Volcano, Japan, as inferred from geomagnetic field variations and electrical structure, J. Volcanol. Geotherm. Res., 189, 158-171.

Kato, A., Terakawa, T., Yamanaka, Y., Maeda, Y., Horikawa, S., Matsuhiro, K., Okuda, T., 2015. Preparatory and precursory processes leading up to the 2014 phreatic eruption of Mount Ontake, Japan, Earth Plants, Space, 67, DOI 10.1186/s40623-015-0288-x.

Kyoto University, Tokyo Institute of Technology, Kagoshima University, 1981. Eruption on September 28, 1980 at Kuchinoerabujima Volcano, 20, 1-9.

Mogi, K., 1958. Relation between the eruptions of various volcanoes and the deformations of the ground surface around them, Bull. Earthq. Res. Inst., Univ. Tokyo, 38, 99-134.

Mori, T., 2007. Measurement of sulfur dioxide emission rate using COMPUSS at Kuchinoerabujima Volcano, Reports on Practical Study on Prediction of Phreatic Eruption and Its Change at Kuchinoerabujima Volcano, Japan, Disast. Prev. Res. Inst., 65-70.

Mori, T., Kazahaya, K., Ohwada, M., Geshi, N., Hirabayashi, J., Yokoo, A., Tada, M., Kanda, W., Tameguri, T., Iguchi, M., Shinohara, H., 2009. Measurement of sulfur dioxide emission rate at Kuchinoerabujima Volcano, Abstracts of 2009 Fall Meeting of Volcanological Society of Japan, B24.

Mori, T., Morita, M., Iguchi, M., Fukuoka Regional Headquarters, 2017. Sulfur dioxide flux monitoring using a public ferry after the 2014 eruption of Kuchinoerabujima Volcano, Japan, Jour. Nat. Disast. Sci. (in this issue).

Nakamichi, H., Kumagai, H., Nakano, M., Okubo, M., Kimata, F., Ito, Y., Obara, K., 2009. Source mechanism of a very-long-period event at Mt Ontake, central Japan: Response of a hydrothermal system to magma intrusion beneath the summit, Jour. Volcanol. Geotherm. Res., 187, 167-177.

Nakano, T., 1932. Eruption in 1931 at Kuchinoerabujima Volcano, Bull. Volcanol. Soc. Japan, 1, 69-72.

Nakao, S., Morita, Y., Yakiwara, H., Oikawa, J., Ueda, H., Takahashi, H., Ohta, Y., Matsushima, T., Iguchi, M., 2013. Volume change of the magma reservoir relating to the 2011 Kirishima Shinmoe-dake eruption - Charging, discharging and recharging process inferred from GPS measurements, Earth Planets Space, 65, 505-515.

Ohminato, T., Kaneko, T., Koyama, T., Watanabe, A., Kanda, W., Tameguri, T., 2016. Reconstruction of the Seismic Observation Network at the Summit Area of Kuchinoerabujima by Using an Unmanned Helicopter, Ann., Disast. Prev. Res. Inst., Kyoto Univ., 59, 76-83.

Ohminato, T., Kaneko, T., Koyama, T., Watanabe, A., Kanda, W., Tameguri, T., Kazahaya, R., 2017. Observations using an unmanned aerial vehicle in an area in danger of volcanic eruptions at Kuchinoerabujima Volcano, southern Kyushu, Japan, Jour. Nat. Disast. Sci. (in this issue).

Saito, E., Iguchi, M., 2006. Ground deformation detection at Kuchinoerabujima Volcano by continuous GPS with simple atmospheric correction, Bull. Volcanol. Soc. Japan, 51, 21-30.

Saito, E., Iguchi, M., Matsushima, N., 2015. Ground deformation revealed by GPS observation for 10 years before the 2014 eruption in Kuchinoerabujima Volcano, Bull. Geol. Surv. Japan, vol.66 (5/6), 103-141. 
Tanakadate, H., 1938. Eruption at Shindake of Kuchinoerabujima Volcano, Topography of the crater and mud flow at Mukaehama, Bull. Volcanol. Soc. Japan, 4, 339-354.

Triastuty, H., Iguchi, M., Tameguri, T., 2009. Temporal change of characteristics of shallow volcanotectonic earthquakes associated with increase in volcanic activity at Kuchinoerabujima Volcano, Japan, Jour. Volcanol. Geotherm. Res, 187, 1-12.

Yamamoto, K., Ohkura, T., Yokoo, A., Tameguri, T., Sonoda, T., Inoue, H., 2017. Vertical ground deformation related with the 2014 and 2015 eruptions at Kuchinoerabujima Volcano, Japan, detected by repeated precise leveling surveys, Jour. Nat. Disast. Sci. (in this issue).

Yamasato, H., Funasaki, J., Takagi, Y., 2013. The Japan Meteorological Agency's Volcanic Disaster Mitigation Initiatives, Technical Note of the NIED, 380, 101-107. 